Short Communication

\title{
Expression profiles of sugarcane under drought conditions: Variation in gene regulation
}

\author{
Júlio César Farias de Andrade ${ }^{1}$, Jackeline Terto ${ }^{1}$, José Vieira Silva ${ }^{2}$ and Cícero Almeida ${ }^{1}$ \\ ${ }^{1}$ Laboratório de Recursos Genéticos, Campus Arapiraca, Universidade Federal de Alagoas, \\ Arapiraca, AL, Brazil. \\ ${ }^{2}$ Laboratório de Fisiologia de Plantas, Universidade Federal de Alagoas, Arapiraca, AL, Brazil.
}

\begin{abstract}
Drought is a major factor in decreased sugarcane productivity because of the resulting morphophysiological effects that it causes. Gene expression studies that have examined the influence of water stress in sugarcane have yielded divergent results, indicating the absence of a fixed pattern of changes in gene expression. In this work, we investigated the expression profiles of 12 genes in the leaves of a drought-tolerant genotype (RB72910) of sugarcane and compared the results with those of other studies. The genotype was subjected to $80-100 \%$ water availability (control condition) and $0-20 \%$ water availability (simulated drought). To analyze the physiological status, the SPAD index, $\mathrm{Fv} / \mathrm{Fm}$ ratio, net photosynthesis $(\mathrm{A})$, stomatal conductance $\left(g_{s}\right)$ and stomatal transpiration $(E)$ were measured. Total RNA was extracted from leaves and the expression of SAMDC, ZmPIP2-1 protein, ZmTIP4-2 protein, WIP protein, LTP protein, histone H3, DNAj, ferredoxin I, $\beta$-tubulin, photosystem I, gene 1 and gene 2 was analyzed by quantitative real-time PCR (RT-PCR). Important differences in the expression profiles of these genes were observed when compared with other genotypes, suggesting that complex defense mechanisms are activated in response to water stress. However, there was no recognizable pattern for the changes in expression of the different proteins associated with tolerance to drought stress.
\end{abstract}

Keywords: gene expression, plant breeding, quantitative RT-PCR.

Received: October 31, 2014; Accepted: March 23, 2015.

Sugarcane belongs to the genus Saccharum L., tribe Andropogoneae, family Poaceae. Modern commercial varieties are derived from a cross between $S$. officinarum and $S$. spontaneum that, after successive backcrossing with $S$. officinarum, resulted in cultivars with $2 n=100-130$ chromosomes containing approximately $80 \% \mathrm{~S}$. officinarum, $10 \%$ S. spontaneum and $10 \%$ recombinants of the two genomes (D'Hont et al., 1996; Grivet and Arruda, 2001).

Sugarcane is of great commercial importance since it accounts for $\sim 65 \%$ of sugar production worldwide. In addition to sugar, ethanol derived from sugarcane provides a renewable alternative fuel that causes less pollution to the environment than oil (Carson and Botha, 2002). Modern sugarcane cultivars are highly productive in tropical regions. However, drought is a major cause of decreased productivity because of the morphophysiological effects that water deficiency causes to sugarcane, e.g., reduced photosynthesis and growth inhibition. These limitations have stimulated breeding programs to develop new varieties of

Send correspondence to Cícero Almeida. Universidade Federal de Alagoas, Campus de Arapiraca, Avenida Manoel Severino Barbosa $\mathrm{s} / \mathrm{n}$, Rodovia AL 115, km 6,5, Arapiraca, AL, Brazil. E-mail: cicerocarlos@pesquisador.cnpq.br. sugarcane with greater efficiency of water use (Yordanov et al., 2000; Silva et al., 2008; Ghannoum, 2009).

The mechanisms of plant stress responses are highly important to agriculture because of their direct link to production systems. Proteins such as heat shock proteins, peroxidases and water transport proteins are involved in plant protection mechanisms under conditions of low water availability (Xiong et al., 2002; Casu et al., 2005; Wang et al., 2004; Borges et al., 2001). In addition, differential expression of some sugarcane genes associated with tolerance to water stress has been reported. Thus, Rodrigues et al. (2009) analyzed 3,575 ESTs in a drought-tolerant sugarcane cultivar and found 165 differentially expressed genes, indicating a large number of genes associated with drought tolerance. However, there is currently no information on the gene expression patterns in other genotypes classified as tolerant. In this study, we examined the gene expression profiles in leaves of the drought-tolerant sugarcane cultivar RB72910 under drought conditions and compared them to the expression profiles of other accessions.

The experiment was done in a greenhouse using two treatments: a control treatment and a water stress treatment with four replications in a completely randomized experimental design. Each plot consisted of a pot containing one 
plant. The genotype RB72910 assigned by the Sugarcane Breeding Program (PMGCA/RIDESA/UFAL) and classified as highly tolerant to drought was used for this study. To ensure greater homogeneity of seedlings, buds were pregrown in individual boxes $(40 \mathrm{~cm}$ long $\mathrm{x} 30 \mathrm{~cm}$ wide $\mathrm{x}$ $10 \mathrm{~cm}$ high) containing a substrate of coconut pulp, filter cake and black earth at a ratio of 1:1:2 (m/m), respectively, and a density of 16 buds per box. The buds were pre-treated with carbendazim fungicide at the concentration recommended by the manufacturer. Fifteen days after planting in the boxes, the best seedlings were transferred and individually planted in plastic pots ( $30 \mathrm{~cm} \times 30 \mathrm{~cm}$ diameter), each one containing $12 \mathrm{~kg}$ of the same substrate as described above.

The humidity for the permanent wilting point (-1.5 MPa) and field capacity (-0.03 MPa) of the substrate dry mass to define treatments were 16.92 and $22.54 \%$, respectively, obtained from a moisture retention curve of the substrate and established by gravimetric analysis. The treatments were defined as follows: moisture close to field capacity for the test without water stress, with $80-100 \%$ water availability (control) and $0-20 \%$ water availability (stressed) for testing under severe stress. All pots from both treatments were weighed daily and their masses corrected according to the available water in the substrate. The pots were kept at a humidity of $80-100 \%$, with daily watering at 08:00 a.m. for up to 66 days of cultivation (DC) in order to replace evapotranspired water. Test measurements were taken during early crop development as this corresponded to the most sensitive period to water stress, and at $70 \mathrm{DC}$ with four days of water deficiency for the stress treatment. To determine the water deficiency status, the physiological variables were analyzed at 68 and 70 days after cultivation (two and four days after water stress, respectively).

The Fv/Fm ratio was obtained by measuring chlorophyll-a fluorescence emission with a portable light-modulated fluorometer (Opti-Sciences, model OS1-FL, Hudson, USA) after the leaves had adapted to the dark ( $\sim 20 \mathrm{~min})$. The maximum fluorescence (Fm) was obtained with the aid of plastic clips, followed by the variable fluorescence (Fv), such that the PSII maximum quantum yield (Fv/Fm ratio) could be determined. Measurements were taken between $11 \mathrm{a} . \mathrm{m}$. and $12 \mathrm{a} . \mathrm{m}$. that corresponded to the most important time with respect to temperature and solar radiation for that region. This was also the period in which there was probably more damage to the photosynthetic apparatus, as shown instantly in the PSII. Two readings were taken in the middle portion of the leaf +1 for each plant.

Measurements of net photosynthesis (A), stomatal conductance $\left(g_{s}\right)$ and stomatal transpiration $(E)$ were made using an IRGA infrared gas analyzer (ADC, model LCi, Hoddesdon, UK) with an air flow of $300 \mathrm{~mL} / \mathrm{min}$ and a coupled light source of $995 \mu \mathrm{mol} / \mathrm{m}^{2} / \mathrm{s}$, at relative humidity and room temperature. The measurements were made between $8 \mathrm{a} . \mathrm{m}$. and 11 a.m. in the middle portion of the leaf +1 , with readings taken for each plant and each repetition. The leaf chlorophyll content was estimated using the SPAD index and an SPAD-502 chlorophylometer (Minolta Corporation, Ramsey, USA), with averages obtained from eight readings for each plant. The variables were analyzed using $R$ package software and the results expressed graphically.

Total RNA was extracted from leaves of control and drought-stressed plants using commercial Trizol reagent (Invitrogen, Carlsbad, USA), according to the manufacturer's instructions. The samples were a mixture of leaves from the four replications of each treatment. cDNA was produced using $2 \mu \mathrm{g}$ of total RNA as the template and a PCR-select cDNA subtraction kit, in which $2 \mu \mathrm{L}$ of total RNA and $1 \mu \mathrm{L}$ of cDNA synthesis primer $(10 \mu \mathrm{M})$ were incubated for $70{ }^{\circ} \mathrm{C}$ for $2 \mathrm{~min}$ in a thermal cycler and then cooled on ice. After $2 \mathrm{~min}, 2 \mu \mathrm{L}$ of $5 \mathrm{x}$ first-strand buffer, $1 \mu \mathrm{L}$ of dNTP ( $10 \mathrm{mM}$ each), $1 \mu \mathrm{L}$ of sterile $\mathrm{H}_{2} \mathrm{O}$ and one microliter of AMV reverse transcriptase $(20$ units $/ \mu \mathrm{L})$ were added and the reaction was incubated for $90 \mathrm{~min}$ at $42^{\circ} \mathrm{C}$ in an air incubator.

The expression profiles of 12 genes (Table 1) in sugarcane leaves (RB72910 genotype) under drought-stress and a no-stress control were analyzed by real-time RTPCR. The sugarcane $\beta$-tubulin gene was used as an internal reference (housekeeping gene), as described by Iskandar $e t$ al. (2004) and Rodrigues et al. (2009) for relative expression of the 11 genes. The real-time PCR reactions were done using SYBR Green master mix (Fermentas) in an ABI 7500 thermocycler containing $65 \mathrm{ng}$ of cDNA, $25 \mathrm{nM}$ of each primer and $12.6 \mu \mathrm{L}$ of SYBR Green master mix in a final volume of $25 \mu \mathrm{L}$. Amplification was done at $50^{\circ} \mathrm{C}$ for $2 \mathrm{~min}, 95^{\circ} \mathrm{C}$ for $10 \mathrm{~min}$ and 40 cycles at $95^{\circ} \mathrm{C}$ for $15 \mathrm{~s}$ and $60^{\circ} \mathrm{C}$ for $1 \mathrm{~min}$. Three replicates were run and analyzed independently.

The sugarcane genotype used in this study has a high growth capacity in conditions of low water availability (data from PMGCA-RIBESA). The genes examined here were reported by Rodrigues et al. (2009) to show different levels of expression in association with tolerance to drought stress. In the present study, the physiological development of plants was assessed using the SPAD index, $\mathrm{Fv} / \mathrm{Fm}$ ratio, net photosynthesis (A), stomatal conductance (gs) and stomatal gas exchange or transpiration (E). As shown in Table S1, there was a significant difference in A, gs and $\mathrm{E}$ when the genotype was grown under conditions of low water availability. Net photosynthesis decreased from $11 \mu \mathrm{mol} \mathrm{CO}{ }_{2} / \mathrm{m}^{2} / \mathrm{s}$ in control plants to $3.6 \mu \mathrm{mol} \mathrm{CO} / \mathrm{m}^{2} / \mathrm{s}$ in the stress-treated plants. For gas exchange, the results were $2.09 \mathrm{mmol} \mathrm{H}_{2} \mathrm{O} / \mathrm{m}^{2} / \mathrm{s}$ for control plants and $0.79 \mathrm{mmol}$ $\mathrm{H}_{2} \mathrm{O} / \mathrm{m}^{2} / \mathrm{s}$ for stressed plants, while for stomatal conductance the results were 0.11 and $0.03 \mathrm{mmol} \mathrm{H}_{2} \mathrm{O} / \mathrm{m}^{2} / \mathrm{s}$ for control and stressed plants, respectively (Figure 1).

Gene expression was assessed in triplicate using quantitative PCR. The $\mathrm{Ct}$ values for each gene under differ- 
Table 1 - Genes analyzed by quantitative real-time RT-PCR and their regulation profiles.

\begin{tabular}{|c|c|c|c|c|c|}
\hline \multirow{2}{*}{$\begin{array}{l}\text { GenBank accession } \\
\text { number }\end{array}$} & \multirow[t]{2}{*}{ Gene } & \multirow[t]{2}{*}{ Description $^{\mathrm{b}}$} & \multicolumn{3}{|c|}{ Regulation profile } \\
\hline & & & RB72910 & SP83-5073 ${ }^{b}$ & SP90-1638 \\
\hline CA222437 & $\beta$-Tubulin & Housekeeping gene & - & - & - \\
\hline CA127376 & SAMDC & S-adenosylmethionine decarboxylase [EC 4.1.1.50] [Zea mays] & Down & Up & - \\
\hline CA120560 & Protein ZmPIP2-1 & Plasma membrane integral protein ZmPIP2-1 [Zea mays] & Down & Up & - \\
\hline CA128872 & Protein ZmTIP4-2 & Tonoplast membrane integral protein ZmTIP4-2 [Zea mays] & Up & - & Up \\
\hline CA127367 & Protein WIP & Wound-induced protein [Medicago sativa subsp. varia] & Down & Up & Up \\
\hline CA119309 & Protein LTP & Lipid transfer protein $[$ Setaria italica $]$ & Down & Up & Down \\
\hline CA116806 & Histone & Histone H3 (H3-1.1) [Oryza sativa] & Down & Up & Up \\
\hline CA300174 & DNAj & DNAj protein & Up & Down & Up \\
\hline CA293774 & Ferredoxin I & Ferredoxin I, chloroplast precursor (Fd I) [Zea mays] & Up & - & Down \\
\hline CA116652 & Photosystem I & Photosystem I complex PsaN subunit precursor [Zea mays] & Dow & - & Down \\
\hline CA122935 & Gene1 & No match & Up & Up & Down \\
\hline CA129393 & Gene2 & No match & Down & Up & Up \\
\hline
\end{tabular}

${ }^{a}$ Gene accession number in the NCBI database. ${ }^{b}$ Described as tolerant by Rodrigues et al. (2009). ${ }^{c}$ Described as sensitive by Rodrigues et al. (2009).
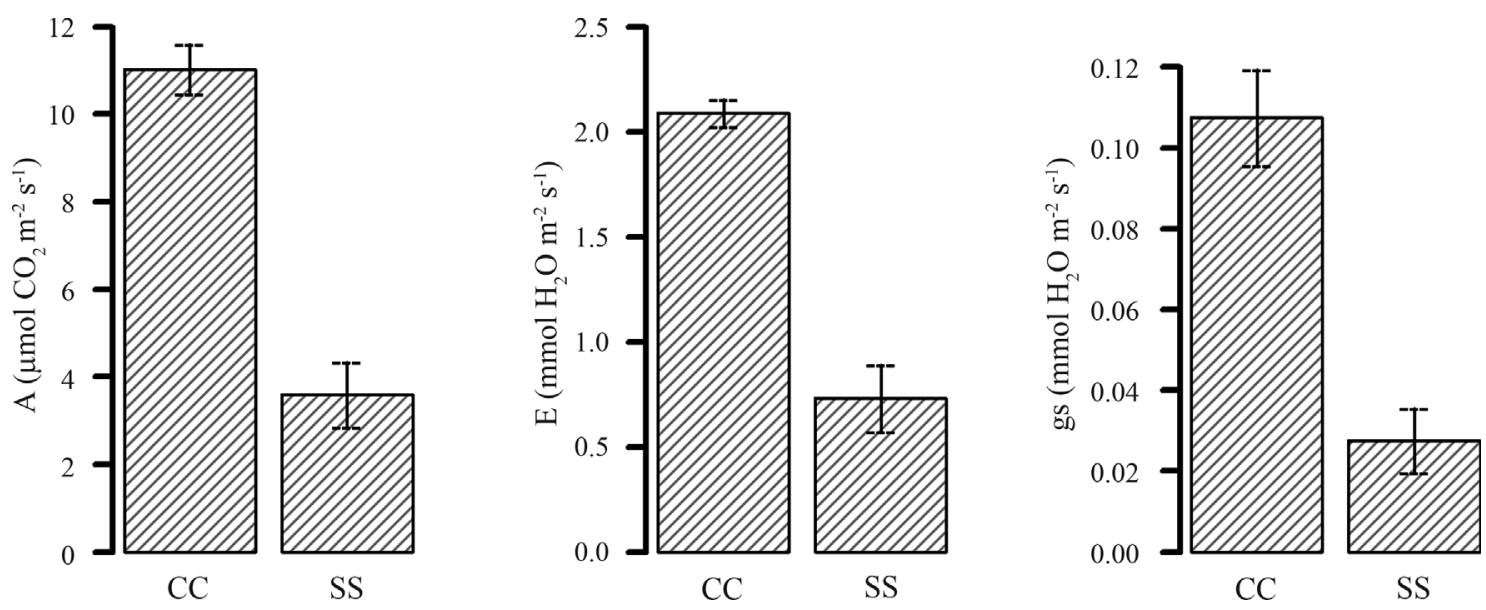

Figure 1 - Physiological parameters of plants during water deficiency. Net photosynthesis (A), stomatal conductance $\left(g_{s}\right)$, stomatal transpiration $(E)$. Error bars indicate the standard deviation $( \pm \mathrm{sd})$.

ent experimental conditions (Figure 2) were used to obtain the relative level of gene expression by $2^{-\Delta \Delta \mathrm{Ct}}$ methodology, with $\beta$-tubulin as the reference gene (Figure 3 ). There were no changes in the expression of gene 1 , histone, photosystem I, ZmTIP4-2 and SAMDC, while DNAj, gene 2 and ferrodoxin 1 showed small alterations in expression. In contrast, when analyzed by real time RT-PCR (Figure 2) and semi-quantitative PCR (Figure S1), there were marked changes in the expression of LTP protein, WIP protein and ZmPIP2-1 (Figure 3). Under conditions of water stress, the DNAj and $\beta$-tubulin genes showed enhanced and decreased expression, respectively.

Genomic, transcriptomic, proteomic and metabolomic studies have sought to elucidate the mechanisms of plant responses to drought stress. The responses observed in these investigations include changes in the expression of genes associated with plant maintenance, protein synthesis and turnover, and metabolic alterations (reviewed by Shanker et al., 2014). However, the patterns of gene expression vary among different genotypes, indicating that there are different responses associated with water stress.

The sugarcane genotype RB72910 was identified by the PMGCA/RIDESA Breeding Program as being drought-tolerant and Rodrigues et al. (2009, 2011) described another genotype (SP83-5073) as tolerant to water stress. Since these two genotypes showed similar tolerance, one would expect similar profiles of gene expression in response to water stress. However, this was not the case since no stability was noted in the expression levels of the two genotypes. Comparison of the expression of 12 genes in a drought-tolerant genotype with those described by Rodrigues et al. (2009) indicated important differences in the expression profiles of the two genotypes (Table 1); these differences suggest the existence of divergent mechanisms 


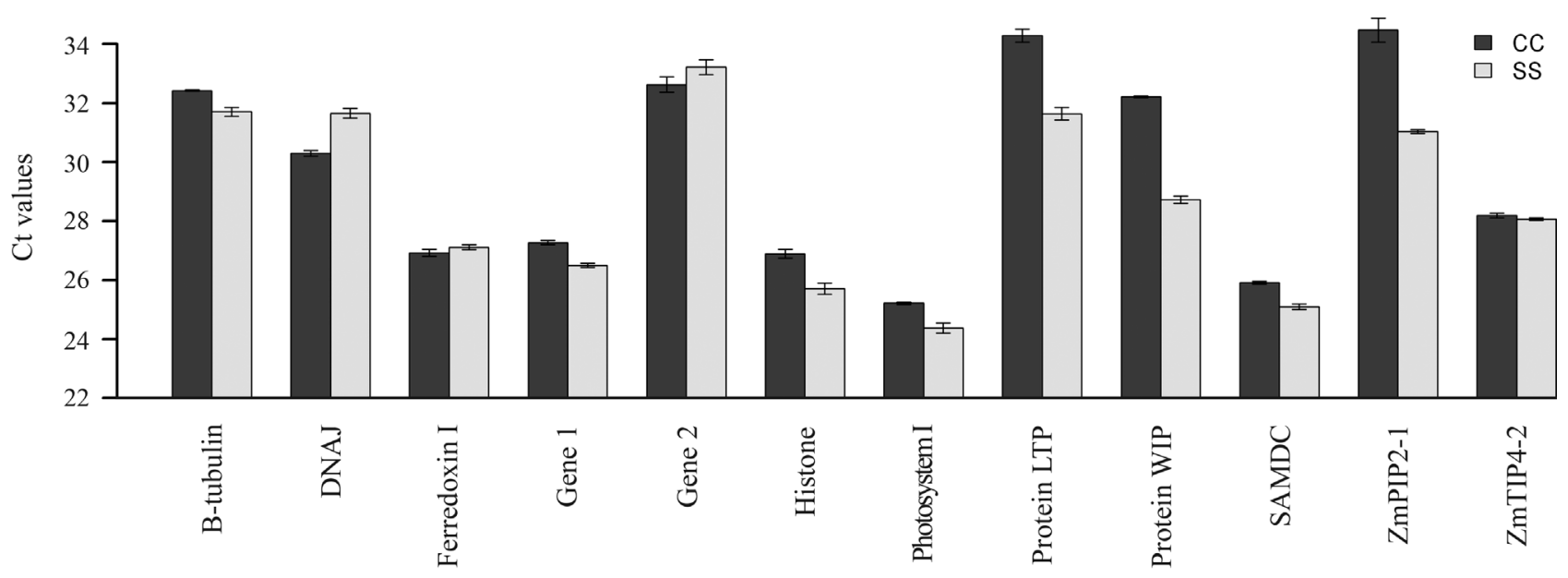

Figure 2 - RNA transcription profiles represented as cycle threshold $(\mathrm{Ct})$ values in different genes. Error bars indicate the standard deviation $( \pm \mathrm{sd})$.

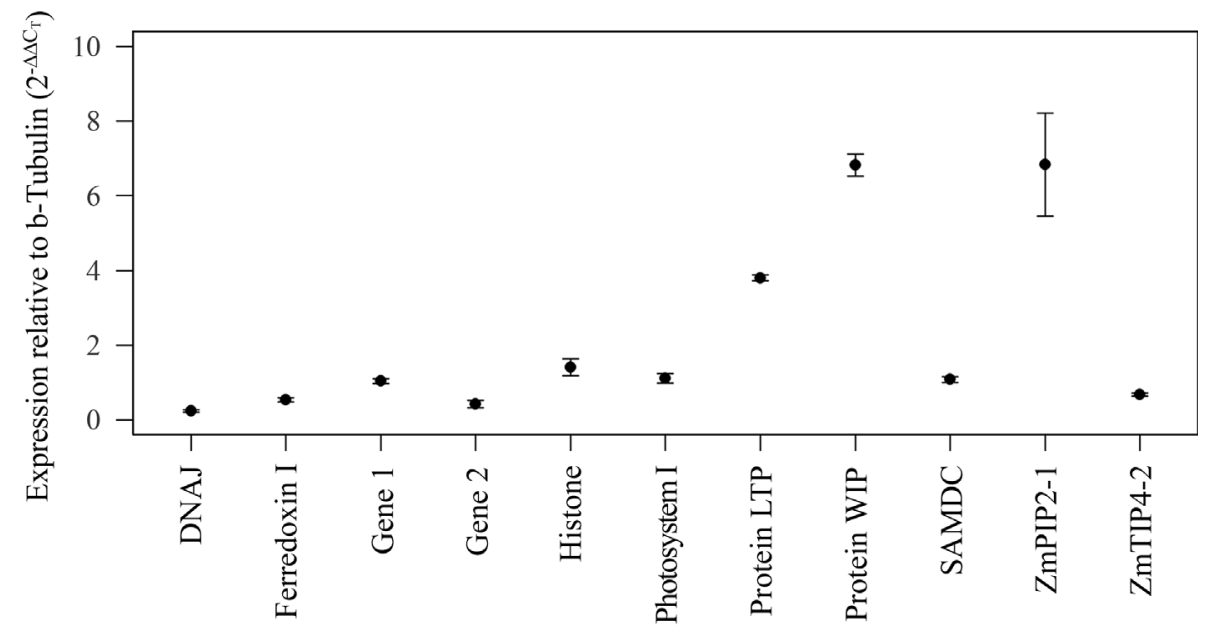

Figure 3 - Relative gene expression analyzed by real-time PCR. Relative quantification was performed through the $2^{-\Delta \Delta C t}$ method using $\beta$-tubulin as the reference gene. Error bars indicate the standard deviation $( \pm \mathrm{sd})$.

for dealing with drought tolerance. Although these differences could be explained by the use of different experimental conditions, it should be noted that the experimental conditions were similar in the two studies. The major differences involved ZmPIP2-1, WIP protein, LTP protein and DNAj, as mentioned above.

A data mining analysis for sugarcane done using the Sugarcane Expressed Sequence Tags (SUCEST) database revealed an abundant expression of genes encoding chaperones, co-chaperones and other proteins linked to protection against stress in sugarcane (Borges et al., 2001). The genes most commonly encountered by Borges et al. (2001) were those responsible for the synthesis of chaperone HSP70 (heat-shock protein) and its co-factors such as HSP40, in addition to encoders of the proteins HSP90, HSP100 and small HSP chaperones (Wang et al., 2004). The chaperone activity of small HSPs has been associated with the heat stress response in sugarcane (Tiroli and Ramos, 2007). Gene expression profiles analyzed by micro- arrays in sugarcane leaves identified 165 genes in response to water stress (Rodrigues et al., 2009).

The enhanced expression of DNAj or HSP40 obtained by subjecting genotype RB72910 to water stress corroborated the data from in silico analysis showing that in conditions of limited water availability these genes were widely expressed. Based on cultivar behavior and productivity in field experiments, RB72910 is classified as tolerant to water stress in the RIDESA sugarcane breeding program database. However, DNAj showed up-regulation in sugarcane (Rodrigues et al., 2009) and potato (VasquezRobinet et al., 2008) genotypes, suggesting that RB72910 has a different mechanism of drought tolerance.

WIP protein is responsible for the restoration of plant tissues after attack by herbivores and abiotic agents. Enhanced expression of this protein is expected under conditions of stress, while ZmPIP2-1, which belongs to the aquaporin protein group, is expressed when the cells are in elongation. As shown here, both of these genes showed re- 
duced expression in RB72910, in contrast to the findings of Rodrigues et al. (2009). According to Cheong et al. (2002), differences in gene expression may reflect the activation of defense mechanisms, including the reorganization of metabolism.

Plant leaves have a surface cuticle that provides a protective barrier against environmental adversities, such as drought. Lipid transfer protein (LTP) is present on leaves, but its functions are not yet known. Our results showed that LTP was down-regulated during water deficiency in RB72910; Rodrigues et al. (2009) reported similar findings for this genotype. The $\beta$-tubulin gene has been used as a reference gene in other studies (Iskandar et al., 2004; Rodrigues et al., 2009), but our findings indicated variability/instability in the expression of this gene.

Overall, the results of this investigation show that the patterns of gene expression vary in different genotypes classified as drought-tolerant. This variability suggests a high degree of complexity in the response of sugarcane to water stress. Studies looking at the patterns of gene expression in plants with different responses to water stress provide one approach for identifying the genes involved. However, the interpretation of these results requires caution since genotypes with morphological and physiological characteristics associated with tolerance to drought stress may exhibit distinct patterns of gene expression; such divergent expression could lead to false positive results, i.e., genes being incorrectly associated with tolerance to drought stress.

\section{Acknowledgments}

We thank Empresa Brasileira de Pesquisas Agropecuárias (EMBRAPA - Tabuleiros Costeiros) for allowing use of the greenhouse, the Federal University of Alagoas for the use of laboratories and scientific support, and Fundação de Apoio à Pesquisa de Alagoas (FAPEAL) for funding this project.

\section{References}

Borges JC, Peroto MC and Ramos CHI (2001) Molecular chaperone genes in the sugarcane expressed sequence database (SUCEST). Genet Mol Biol 24:85-92.

Carson DL and Botha FC (2002) Genes expressed in sugarcane maturing internodal tissue. Plant Cell Reports 20:10751081.

Casu RE, Manners JM, Bonnet GD, Jackson PA, McIntyre CL, Dunne R, Chapman SC, Rae AL and Grof CPL (2005) Genomics approaches for the identification of genes determining important traits in sugarcane. Field Crop Res 92:137-147.

Cheong YH, Chang H-SC, Gupta R, Wang X, Zhu T and Luan S (2002) Transcriptional profiling reveals novel interactions between wounding, pathogen, abiotic stress, and hormonal responses in Arabidopsis. Plant Physiology 129:661-677.
D'Hont A, Grivet L, Feldmann P, Rao S, Berding N and Glaszmann JC (1996) Characterization of the double genome structure of modern sugarcane cultivars (Saccharum spp) by molecular cytogenetics. Mol Genet Genomics 250:405-413.

Ghannoum O (2009) C4 photosynthesis and water stress. Ann Bot 103:635-644.

Grivet L and Arruda P (2001) Sugarcane genomics: Depicting the complex genome of an important tropical crop. Plant Biol 5:122-127.

Iskandar HM, Simpson RS, Casu RE, Bonnett GD, Maclean DJ and Manners JM (2004) Comparison of reference genes for quantitative real-time polymerase chain reaction analysis of gene expression in sugarcane. Plant Mol Biol Rep 22:325337.

Rodrigues FA, Laia ML and Zingaretti SM (2009) Analysis of gene expression profiles under water stress in tolerant and sensitive sugarcane plants. Plant Sci 176:286-302.

Rodrigues FA, Graça JP, Laia ML, Nhani-Jr A, Galbiati JA, Ferro MIT, Ferro JA and Zingaretti SM (2011) Sugarcane genes differentially expressed during water deficit. Biol Plant 55:43-53.

Shanker AK, Maheswari M, Yadav SK, Desai S, Divya B, Neha BA and Venkateswarlu B (2014) Drought stress responses in crops. Funct Integr Genomics 14:11-22.

Silva MA, Silva JAG, Enciso J, Sharma V and Jifon J (2008) Yield components as indicators of drought tolerance of sugarcane. Sci Agric 65:620-627.

Tiroli AO and Ramos CHI (2007) Biochemical and biophysical characterization of small heat shock proteins from sugarcane. Involvement of a specific region located at the N-terminus with substrate specificity. Int J Biochem Cell Biol 39:818-831.

Vasquez-Robinet C, Mane SP, Ulanov A, Watkinson JI, Stromberg VK, Koeyer DD, Schafleitnes R, Willmot DB, Bonierbales M, Bohnert HJ, et al. (2008) Physiological and molecular adaptations to drought in Andean potato genotypes. J Exp Botany 59:2109-2123.

Wang W, Vinocur B, Shoseyov O and Altman A (2004) Role of plant heat-shock proteins and molecular chaperones in the abiotic stress response. Trends Plant Sci 9:244-252.

Xiong L, Schumaker KS and Zhu JK (2002) Cell signaling during cold, drought, and salt stress. Plant Cell 14:165-183.

Yordanov I, Velikova V and Tsonev T (2000) Plant responses to drought, acclimation, and stress tolerance. Photosynthetica 38:171-186.

\section{Supplementary Material}

The following online material is available for this article: Figure S1 - Differential gene expression in the sugarcane genotype RB72910.

Table S1 - Statistical analysis for the physiological traits. This material is available as part of the online article from http://www.scielo.br/gmb.

\section{Associate Editor: Dario Grattapaglia}

License information: This is an open-access article distributed under the terms of the Creative Commons Attribution License (type CC-BY), which permits unrestricted use, distribution and reproduction in any medium, provided the original article is properly cited. 